Khazanah: Jurnal Studi Islam dan Humaniora

ISSN: 0215-837X (p); 2460-7606 (e), Vol. 19 (1), 2021, pp. 1-20

DOI: 10.18592/khazanah.v19i1.4336

Submit: 02/01/2021 Review: 20/03/2021 Publish: 30/07/2021

\title{
MENYIKAPI AKTIVITAS BERJAMAAH DI MASJID SELAMA PANDEMI COVID-19: ANALISIS RESPON MASYARAKAT DALAM PERSPEKTIF TEOLOGIS
}

\author{
Muhammad Thohir; Nalindra Isnan Pangestu; Fiha Ainun Jariyah; \\ Puga Sakti Wibowo \\ UIN Sunan Ampel Surabaya \\ muhammadthohir@uinsby.ac.id; inalindra65@gmail.com; fiha.aii99@gmail.com; \\ pugasakti.w@gmail.com
}

\begin{abstract}
The cluster of mosques affected by Covid-19 in the Surabaya city due to congregational activities has attracted the attention of various parties. The government, the Indonesian Ulama Council, and several mass organizations appeal to the public to obey health procedures while in the mosque. This research aims to explain in a theological perspective the public response in responding to congregational activities in mosques during the Covid-19 outbreak. The method used is a mixed-method by distributing quantitative questionnaires and combining qualitative data. The results of the study revealed that at least the Muslims were divided into three groups, namely First, those who surrendered to their destiny did not make zahir efforts in dealing with this epidemic, so they remained in congregation in mosques without maintaining health protocols; Second, the Muslims who are too paranoid, use every effort to take precautions in a zabir manner but are ignorant of spiritual matters; Third, the middle Muslims, namely those who are balanced, they remain in the congregation but still follow health protocols. The attitude that should be applied is the third attitude: physically and mentally and ending with tawakal. These findings offer new knowledge about the relationship between the theological attitudes of society and the attitudes of previous Muslim scholars as historical normative justification.
\end{abstract}

Keywords: Mosque, Covid-19, Jabariyah, Qadariyah, Abl al-Sunnah wa al-Jamaah

\begin{abstract}
Abstrak: Kluster masjid sebagai terdampak covid-19 di Kota Surabaya akibat aktivitas berjamaah mengundang perhatian berbagai pihak. Pemerintah, MUI dan beberapa ormas menghimbau masyarakat untuk mentaati proedur kesehetan selama di Masjid. Riset ini bertujuan untuk menjelaskan dalam perspektif teologi tentang respons masyarakat dalam menyikapi kegiatan berjamaah di masjid pada masa wabah Covid-19. Metode yang digunakan adalah mixed method dengan menyebarkan angket kuantitatif dan dipadukan data kualitatif. Hasil penelitian mengungkapkan babwa setidaknya kaum muslim terbagi dalam tiga kelompok, yakni Pertama, mereka yang pasrab dengan takdir, tidak berusaha secara dzahir dalam menyikapi wabah ini, sehingga mereka tetap berjamaah di masjid tanpa mempertahankan protokol kesehatan; Kedua, kaum muslimin yang terlalu paranoid, menggunakan segala usaha untuk melakukan pencegahan secara dzabir namun abai dalam masalah rubiyah; Ketiga, kaum muslimin yang pertengahan, yakni mereka yang seimbang, mereka tetap berjamaah tetapi tetap mengikuti protokol kesehatan. Sikap yang semestinya diterapkan adalah sikap ketiga dengan berusaba secara labir dan batin serta diakhiri dengan tawakal. Temuan penelitian ini menawarkan pengetahuan baru tentang relasi sikeap teologis masyarakat dengan sikap para ulama terdahulu sebagai justifikasi normatif historis.
\end{abstract}

Kata kunci: Masjid, Covid-19, Jabariyah, Qadariyah, Abl al-Sunnah wa al-Jamaah 
Muhammad Thohir; Nalindra Isnan Pangestu; Fiha Ainun Jariyah;

Puga Sakti Wibowo

\section{Pendahuluan}

Coronavirus Disease 2019 atau biasa disingkat dengan Covid-19 pertama kali dilaporkan muncul pada awal Desember 2019 di Wuhan, Cina. Kasus pertama kali yang berada di luar Cina terkonfirmasi pada 13 Januari 2020 di Bangkok, Thailand. Pada 2 Maret 2020, 67 wilayah di luar Cina melaporkan bahwa telah terkonfirmasi sejumlah 8565 kasus positif dengan kematian 132 jiwa, serta transmisi komunitas yang signifikan berlangsung dalam beberapa negara di dunia, termasuk Iran dan Italia. Setelah itu, pada 11 Maret 2020, Covid-19 ditetapkan sebagai pandemi global oleh WHO. ${ }^{1}$

Pada 2 Maret 2020 terkonfirmasi kasus Covid-19 pertama di Indonesia, yakni seorang wanita berusia 64 tahun dan anak perempuannya yang berusia 31 tahun. Dua orang tersebut telah berinteraksi langsung dengan warga Jepang yang datang ke Indonesia pada awal Februari, warga Jepang tersebut terkonfirmasi positif Covid-19 setelah menjalani tes di Malaysia pada 27 Februari 2020. ${ }^{2}$ Hingga pada 28 Juni 2020, telah terkonfirmasi 54.010 kasus dengan jumlah kematian 2.754 dan yang sembuh sebanyak 22.936. ${ }^{3}$

Berbagai upaya dari pemerintah Indonesia telah dilakukan untuk menghambat dan menghentikan penyebaran Covid-19 di Indonesia, seperti memberlakukan WFH (Work From Home) bahkan aktivitas pendidikan pun dialihkan dengan program belajar di rumah hingga kondisi yang dinilai aman untuk kembali beraktivitas normal seperti biasanya. Usaha lain yang dilakukan pemerintah salah satunya adalah dengan menghimbau agar tempat-tempat yang berpotensi terjadi banyak kerumunan masa termasuk tempat-tempat peribadatan untuk ditutup sementara waktu.

Indonesia memiliki jumlah penduduk Muslim terbesar di dunia, berdasarkan data BPS tahun 2010 diketahui bahwa dari 237.641.326 penduduk Indonesia 207.176.162 di antaranya beragama Islam, yakni sekitar 87.18\% dari total jumlah penduduk Indonesia. ${ }^{4}$ Sikap umat Islam terkait wabah Covid-19 ini tentu berimplikasi besar terhadap kesuksesan penanggulangannya. Umat Islam sebagai penduduk mayoritas tentu diharapkan memiliki sikap positif untuk mendukung segala upaya penanggulangan wabah ini agar segera berhenti dan kehidupan kembali menjadi normal kembali.

${ }^{1}$ Francesco Di Gennaro et al., "Coronavirus Diseases (COVID-19) Current Status and Future Perspectives: A Narrative Review," International Journal of Environmental Research and Public Health 17, no. 8 (2020), 2.

${ }^{2}$ Marchio Irfan Gorbianto, "Breaking: Jokowi Announces Indonesia's First Two Confirmed COVID-19 Cases," The Jakarta Post, accessed June 26, 2020, https://www.thejakartapost.com/news/2020/03/02/breaking-jokowi-announces-indonesias-firsttwo-confirmed-Covid-19-cases.html.

${ }^{3}$ World Health Organization (WHO), "Novel Coronavirus," World Health Organization, last modifld 2020, accessed June 26, 2020, https://www.who.int/indonesia/news/novel-coronavirus/qafor-public.

4"Sensus Penduduk 2010 - Penduduk Menurut Wilayah Dan Agama Yang Dianut Indonesia," accessed June 26, 2020, https://sp2010.bps.go.id/index.php/site/tabel?tid=321\&wid=0. 
Potensi penularan Covid-19 salah satunya disebabkan oleh kerumuman banyak orang dalam satu tempat. Di Kota Surabaya sendiri, rilis ke publik pada tanggal 22 Mei 2020, terdeteksi bahwa kenaikan jumlah kasus mencapai rekor dengan 311 kasus positif Covid-19 dalam sehari. Sebagian di antaranya berasal dari tiga kluster masjid (suarasurabaya.net, 23/05/2020). ${ }^{5}$ Penutupan berbagai tempat -termasuk penutupan masjid di dalamnyasebagai upaya pencegahan penyebaran COVID-19 menimbulkan berbagai sikap dari masyarakat. Seperti berita yang dilansir CNN Indonesia, Tenaga Ahli Utama Kantor Staf Presiden yang diwakili oleh Donny Gahral Adian menyatakan bahwa penutupan masjid dilakukan sebagai upaya untuk mengurangi potensi penularan virus Corona (Covid-19). ${ }^{6}$ Senada dengan hal tersebut, MUI dan beberapa Ormas Islam seperti Muhammadiyah juga mengeluarkan himbauan agar umat Islam tidak melakukan kegiatan berjamaah di masjid terlebih dahulu selama pandemi ini masih berlangsung. Komisi Fatwa MUI mengeluarkan fatwa Nomor 14 Tahun 2020 tentang Penyelenggaraan Ibadah dalam Situasi Terjadinya Wabah Virus Corona atau Covid19 yang berisi 9 poin.

Isi sebagian poinnya adalah menghimbau masyarakat yang berada di wilayah dengan potensi penyebaran tinggi (zona merah) agar tidak melakukan salat Jumat dan menggantinya dengan salat zuhur di kediaman masing-masing, serta masyarakat juga dihimbau agar tidak menyelenggarakan aktivitas keagamaan yang melibatkan banyak orang seperti salat jamaah, tablig akbar, Salat Id dan lain sebagainya. ${ }^{7}$ Majelis Tarjih Muhammadiyah juga mengeluarkan surat edaran terkait tuntunan ibadah dalam kondisi darurat Covid-19 dan salah satu isinya juga menghimbau agar salat lima waktu tetap dilaksanakan sebagaimana seharusnya akan tetapi dilakukan di rumah masing-masing dan tidak perlu dilaksanakan di masjid atau mushala dan sejenisnya yang melibatkan banyak orang, akan tetapi jika terpaksa karena profesi atau sebab lain sehingga terpaksa keluar rumah, maka salatnya tetap dilakukan sebagaimana mestinya dengan menerapkan protokol kesehatan. ${ }^{8}$

Beragam hal yang dilakukan sebagai upaya pencegahan penyebaran wabah Covid-19 ini diharapkan bisa menghambat hingga menghentikan penyebaran wabah ini. Oleh karenanya, khususnya masyarakat muslim, sangat dihimbau agar memperhatikan protokol kesehatan dalam melakukan kegiatan di masjid, termasuk memperhatikan fatwa-fatwa yang telah dirumuskan oleh MUI maupun ormas-ormas Islam seperti Muhammadiyah yang sudah dirumuskan oleh orang-orang yang ahli di bidangnya. Sikap masyarakat terkait himbauan tersebut secara langsung ataupun tidak

${ }^{5}$ Lihat https://www.suarasurabaya.net/kelanakota/2020/sudah-ada-tiga-klaster-masjidrisma-ayolah-salat-id-di-rumah-saja/

"Risiko Penularan Corona Tinggi Alasan Tempat Ibadah Ditutup," CNN Indonesia, n.d., accessed July 13, 2020, www.cnnindonesia.com/nasional/20200528160434-20-507677/risikopenularan-corona-tinggi-alasan-tempat-ibadah-ditutup.

${ }^{7}$ Majelis Ulama Indonesia, "Fatwa Majelis Ulama Indonesia Nomor: 14 Tahun 2020 Tentang Penyelenggaraan Ibadah Dalam Situasi Terjadi Wabah Covid-19,".

8Pimpinan Pusat Muhammadiyah, "Edaran Pimpinan Pusat Muhammadiyah Nomor 02/EDR/1.0/E/2020 Tentang Tuntunan Ibadah Dalam Kondisi Darurat Covid-19,". 
Muhammad Thohir; Nalindra Isnan Pangestu; Fiha Ainun Jariyah;

Puga Sakti Wibowo

akan berpengaruh terhadap kesuksesan upaya pencegahan penyebaran wabah Covid19.

Dana Riksa Buana mengatakan bahwa masyarakat Indonesia mengalami bias kognisi dalam menghadapi pandemi Covid-19 ini. Bias kognisi adalah jenis kesalahan berpikir dalam memahami fenomena yang ada di sekitarnya. Bias kognisi merupakan hasil dari berpikirnya manusia secara sederhana dalam memproses sebuah informasi. ${ }^{9}$ Bias kognisi dalam hal beragama dicontohkan dengan masih banyaknya masyarakat yang masih melakukan kegiatan keagamaan dengan jumlah yang banyak. Mereka meyakini sepenuhnya bahwa hanya dengan doa, mereka akan terhindar dari virus Corona. Mereka meyakini bahwa seharusnya hanya takut kepada Tuhan, dan tidak takut dengan virus Corona. ${ }^{10}$

Beberapa penelitian terdahulu telah dilakukan terkait dengan tema sikap masyarakat terhadap pandemi covid-19 ini. Di antaranya, tahun 2019, hasil penelitian Hammad, Eissa, dan Dawa ${ }^{11}$ telah menjustifikasi bahwa pandemi covid-19 sangat berdampak secara signifikan terhadap perubahan sikap, perilaku dan kesehatan mental masyarakat. Tahun 2020, hasil penelitian Abolfotouh, Almutairi, dan Bani Mustafa, ${ }^{12}$ Utami et.al, ${ }^{13}$ Lestari, ${ }^{14}$ Kartikawati et.al., ${ }^{15}$ dan Noor ${ }^{16}$ telah mengungkap sisi tabir sikap masyarakat yang tidak dalam satu kata sepakat atas realitas wabah. Sementara hasil penelitian Muttaqin et.al. ${ }^{17}$ dan Alwi ${ }^{18}$ lebih melihat para tata kelola masjid secara manajerial terhadap penanggulangan wabah. Adapun dalam tema respon masyarakat muslim terhadap wabah Covid-19 secara teologis telah teliti oleh

${ }^{9}$ Dana Riksa Buana, "Analisis Perilaku Masyarakat Indoensia Dalam Menghadapi Pandemi Virus Corono (Covid-19) Dan Kiat Menjaga Kesejahteraan Jiwa," SALAM: Jurnal Sosial \& Budaya Syar-i 7 , no. 3 (2020), 220.

${ }^{10}$ Ibid., 221.

${ }^{11}$ Hammad, M.A.H., Eissa, M. \& Dawa, G.A. "Impact of Coronavirus Disease 2019 (COVID-19) Pandemic on Attitude, Behavior, and Mental Health of Patients with Rheumatic diseases." Egypt Rheumatol Rehabil 47, 45 (2020), 1-13.

${ }^{12}$ Abolfotouh, M.A., Almutairi, A.F., BaniMustafa, A.A. et al. "Perception and Attitude of Healthcare Workers in Saudi Arabia With Regard to Covid-19 Pandemic and Potential Associated Predictors". BMC Infect Dis 20, 719, (2020), 1-10.

${ }^{13}$ Utami, R.A., Mose, R.E., \& Martini, "Pengetahuan, Sikap dan Keterampilan Masyarakat dalam Pencegahan COVID-19 di DKI Jakarta,” Jurnal Kesehatan Holistic, vol. 4, no. 2, (2020).

${ }^{14}$ Lestari, S., "Sikap Warga Kampung Wisata Warna-Warni (Nani) Terhadap Pandemi Covid19." Seminar Nasional Psikologi UM, (2020), 12-16.

${ }^{15}$ Kartikawati, E., Annisa, R., \& Maesaroh. "Perspektif Sikap Ilmiah Masyarakat Terhadap Pandemi Covid 19,” JIST: Jurnal Indonesia Sosial Teknologi, Vol.2, No. 1, (2020), 49-54.

${ }^{16}$ Noor, D. "Sikap masyarakat dalam Melaksanakan Fatwa MUI tentang Pandemi Covid-19," Jurnal Emanasi, Vol 3, No. 2, (2020), 1-16.

${ }^{17}$ Muttaqin, H., Wahidin, K., Maulana, M.A., \& Juarsih, J. "Pemberdayaan Jamaah Masjid Dan Penanggulangan Dampak Pandemi Covid-19: Studi Lapangan Masjid Baitul Mukhlisin, Desa Pangkalan, Kecamatan Ciawigebang, Kuningan," An-Nufus: Jurnal Kajian Islam, Tasawuf, dan Piskoterapi, Vol.2, No. 1, (2020), 58-76.

${ }^{18}$ Alwi, M.M., "Pemberdayaan Ekonomi Masyarakat Berbasis Masjid di Tengah Pandemi Covid-19," Jurnal Al-Hikmah: Ilmu Dakwah dan Perkembangan Masyarakat, Vol. 18, No. 1, (2020), 99116. 
Mahmuddin dan Syandri ${ }^{19}$ dan Hidayah..$^{20}$ Sayangnya, temuan keduanya lebih bersifat generalisasi fenomenologis atas reaksi umat umat Islam secara keseluruhan, belum spesifik dalam konteks perilaku sosial yang lebih sempit, seperti para pelaku berjamaah di masjid.

Dengan demikian, kajian mengenai sikap masyarakat secara teologis dalam aktifitasnya berjamaah di masjid belum terkaji. Untuk itu, dalam penelitian ini akan dicari tahu bagaimana pandangan masyarakat terkait Covid-19 serta bagaimana sikap mereka terhadap kegiatan berjamaah di masjid pada masa wabah Covid-19 serta implikasinya terhadap kesuksesan pelaksanaan upaya-upaya pencegahan wabah Covid-19. Selain itu, pada riset ini akan dipaparkan bagaimana tipologi aliran dalam Islam dalam memahami takdir sebagai sebuah konsep teologis dan relasinya dalam sikap masyarakat muslim di sekitar masjid terhadap wabah sebagai realitas epidemiologis. Selain itu, kajian ini juga memberikan informasi baru bagaimana relasi sikap teologis masyarakat dengan sikap para ulama terdahulu sebagai justifikasi normatif historis.

Riset ini diharapkan dapat memberikan pertimbangan kepada khalayak umum dalam menyikapi pelaksanaan kegiatan berjamaah di masjid pada masa wabah serta berkontribusi sebagai dorongan kepada masyarakat yang masih menghendaki aktivitas berjamaah di masjid tetap berlangsung pada saat wabah Covid-19 agar mematuhi protokol pencegahan yang telah dirumuskan oleh pemerintah dan instansi lain.

\section{Metode}

Penelitian ini menggunakan metode gabungan atau mixed-method. Metode penelitian gabungan ini menggabungkan penelitian kualitatif dan kuantitatif dalam meneliti satu masalah. Dalam metode ini penelitian dilakukan dengan dua tahap, yakni kuantitatif terlebih dahulu kemudian kualitatif atau sebaliknya. Kedua penelitian tersebut dapat dilakukan secara bersamaan (satu tahap) atau secara bergantian (dua tahap). Metode penelitian ini diharapkan untuk bisa mendapatkan hasil yang lebih utuh dan komprehensif terhadap suatu fenomena atau masalah yang akan dikaji. ${ }^{21}$

Penelitian ini menggunakan strategi eksplanatoris sekuensial dengan melakukan penelitian kuantitatif terlebih dahulu kemudian dilanjutkan dengan penelitian kualitatif. ${ }^{22}$ Penelitian kuantitatif dilakukan dengan menyebarkan angket kuesioner dengan lima skala kemudian dilakukan penggalian data lebih dalam dengan mengajukan beberapa pertanyaan kepada beberapa responden sebelumnya untuk

\footnotetext{
${ }^{19}$ Mahmuddin, R. \& Syandri, S. "Qadariyah, Jabariyah dan Ahlus Sunnah (Studi Komparatif Merespon Kebijakan Pemerintah dan Ulama Mencegah Merebaknya Covid-19)," Bustanul Fuqaha: Jurnal Bidang Hukum Islam, Vol.1, No.2, (2020), 209-222.

${ }^{20}$ Hidayah, N. "Dari Jabariyah, ke Qadariyah, hingga islam progresif: respons muslim atas pandemi Covid-19 di Indonesia," Salam; Jurnal Sosial \& Budaya Syar-i, Vol. 7, No. 5, (2020), 423-438.

${ }^{21}$ A. Muri Yusuf, Metode Penelitian: Kantitatif, Kualitatif, dan Penelitian Gabungan (Jakarta: Kencana, 2014), 236.

22Ibid., 237-238.
} 
Muhammad Thohir; Nalindra Isnan Pangestu; Fiha Ainun Jariyah;

Puga Sakti Wibowo

menindaklanjuti hasil kuesioner yang sudah didapatkan. Responden dari riset ini diambil secara acak dengan waktu secara acak juga dikarenakan riset ini bertujuan untuk mencari tahu respons masyarakat terkait kegiatan berjamaah di masjid pada saat wabah Covid-19 secara umum. Beberapa masjid di Kota Surabaya, seperti Masjid Muhajirin, Masjid ad-Dakwah, Masjid Ngampelsari dan Masjid At-Taqwa, menjadi objek penelitian dan dipilih dengan menggunakan purposive sampling, dengan mengacu pada karakteristik masjid yang masih membuka aktivitas berjamaah. Sedangkan subjek penelitian dipilih secara random dan snowballing, dengan mempertimbangkan karakteristik data yang ingin diperoleh.

Sumber data penelitian ini tidak hanya berdasarkan angket yang disebarkan, tetapi juga diperkuat dengan berita-berita faktual dan rubrik opini dari media masa mainstream, serta berbagai artikel ilmiah yang memiliki relevansi dengan penelitian yang penulis lakukan. Analisis data pada penelitian ini terbagi menjadi dua, yakni: statistik deskriptif dan analisis data model Miles, Huberman dan Saldana. Statistik deskriptif adalah statistik yang mempunyai tugas mengorganisasi dan menganalisis data, angka, agar dapat memberikan gambaran yang teratur, ringkas dan jelas mengenai sesuatu yang diteliti. ${ }^{23}$ Adapun analisis data model Miles, Huberman dan Saldana terdiri dari beberapa tahap, yakni: kondensasi data, penyajian data, kesimpulan atau verifikasi. ${ }^{24}$

\section{Pembahasan \\ Sajian Data}

Pada bagian ini, hasil penelitian disajikan berdasarkan tiga aspek sebagaimana telah disebutkan pada kisi-kisi sebelumnya. Data penelitian ini dirumuskan berdasarkan 56 responden yang tersebar dalam berbagai daerah dan latar belakang yang beragam.

1. Pandangan Masyarakat Terkait Wabah Covid-19

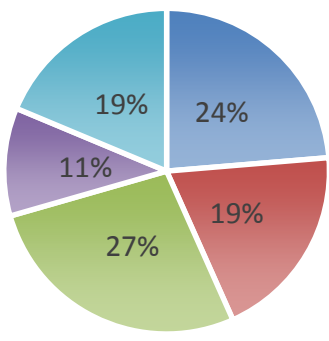

- sangat baik

- baik

cukup

- kurang

- sangat kurang

Gambar 1. Pandangan Masyarakat Terkait Wabah Covid-19 (2016): 345 .

${ }^{23}$ Amirotun Sholikhah, "Statistika Desktiptif Dalam Penelitian Kualitatif," Komunika 10, no. 2

${ }^{24}$ Miles, Huberman, and Saldana, Qualitative Data Analysis: A Methods Sourcebook, Fourth Edition, Sage Publishing, (2014): 10. 
Gambar 1 menjelaskan bahwa sebanyak 24 responden terkategori memiliki pandangan yang baik dan sangat baik terkait wabah Covid-19 ini. Mereka menganggap bahwa wabah Covid-19 memang benar adanya dan memerlukan berbagai macam usaha yang dilakukan sebagai upaya pencegahannya maupun sebagai upaya pengobatannya. Pandangan seperti ini tentu akan berimplikasi positif terhadap usaha-usaha pencegahan wabah Covid-19 ini karena mereka akan cenderung mendukung usaha-usaha yang dilakukan pemerintah dalam menghentikan penyebaran wabah Covid-19. Sejumlah 17 responden terkategori memiliki pandangan yang kurang baik bahkan sangat kurang baik terkait wabah Covid-19 ini. Mereka cenderung memandang Covid-19 ini tidak nyata, ataupun mereka yang menganggap Covid-19 ini sama dengan penyakit flu biasa yang tidak memerlukan perawatan secara intensif serta kecenderungan mereka yang pasrah terhadap takdir yang akan menimpa mereka. Pandangan-pandangan tersebut cukup berbahaya karena mereka akan abai terhadap usaha-usaha yang dilakukan sebagai upaya pencegahan penyebaran wabah Covid-19, mereka akan sangat rentan terinfeksi virus tersebut serta juga sangat berpotensi menularkan kepada orang lain. Sedangkan sebanyak 15 responden lainnya bersikap netral atau terkategori cukup. Mereka masih bimbang terhadap pandangan mereka terkait wabah Covid-19. Skor rata-rata terkait pandangan mereka terhadap wabah Covid-19 dari seluruh responden adalah 3,14 dengan kategori cukup.

2. Sikap Masyarakat Terkait Pembukaan Masjid pada Masa Wabah Covid-19

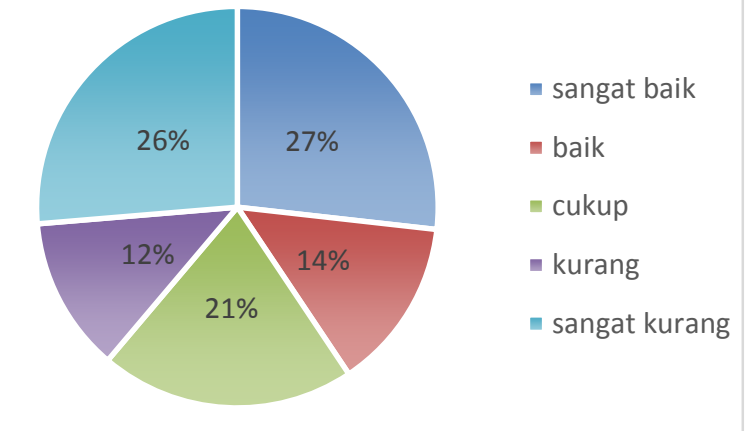

Gambar 2. Sikap Masyarakat Terkait Pembukaan Masjid

Berdasarkan Gambar 2, diperoleh data bahwa sebanyak 23 responden terkategori baik dan sangat baik. Mayoritas dari mereka menghendaki agar masjid tetap dibuka selama wabah Covid-19 tetapi aktivitas berjamaah di masjid tersebut dilaksanakan sesuai dengan prosedur kesehatan. Hal itu dilakukan sebagai salah satu upaya mencegah menyebarnya Covid-19 di masjid. Sebagian mereka yang memilih opsi ini berpendapat bahwa wabah ini datang dari Allah, maka sebaiknya kita memperbanyak ibadah agar wabah ini segera diangkat, sehingga aktivitas berjamaah tetap dilangsungkan akan tetapi dengan memenuhi protokol kesehatan. Sangat sedikit yang menghendaki agar masjid ditutup sepenuhnya selama pandemi. Mereka yang 
Muhammad Thohir; Nalindra Isnan Pangestu; Fiha Ainun Jariyah;

Puga Sakti Wibowo

setuju masjid sementara ditutup beralasan agar penularan Covid-19 tidak semakin meluas, sebaiknya melakukan ibadah dari rumah.

Sejumlah 12 responden terkategori cukup, hal ini dikarenakan mereka cenderung memilih netral ketika diberikan pertanyaan pandangan mereka terkait pembukaan masjid pada masa wabah Covid-19 ini. Sedangkan 21 responden lainnya terkategori kurang dan sangat kurang, sebagian mereka memilih opsi agar masjid dibuka seperti biasanya tanpa menerapkan protokol kesehatan yang sudah dirumuskan oleh pihak yang berwenang. Skor rata-rata sikap masyarakat terkait aktivitas berjamaah di masjid pada wabah Covid-19 adalah 2,95 yang berarti masuk dalam kategori cukup.

Di luar dari responden, Heru Kusuma Hadi dalam siaran Radio Suara Muslim Surabaya pernah menceritakan bahwa selama masa wabah Covid-19 ini terdapat salah satu tetangganya yang sangat menutup diri, dia terlihat sangat khawatir, bahkan ketika ada seseorang lewat di depan rumahnya, dia buru-buru untuk masuk ke dalam rumahnya.

3. Kepatuhan Masyarakat Terkait Protokol Kesehatan di Masjid pada Masa Covid19

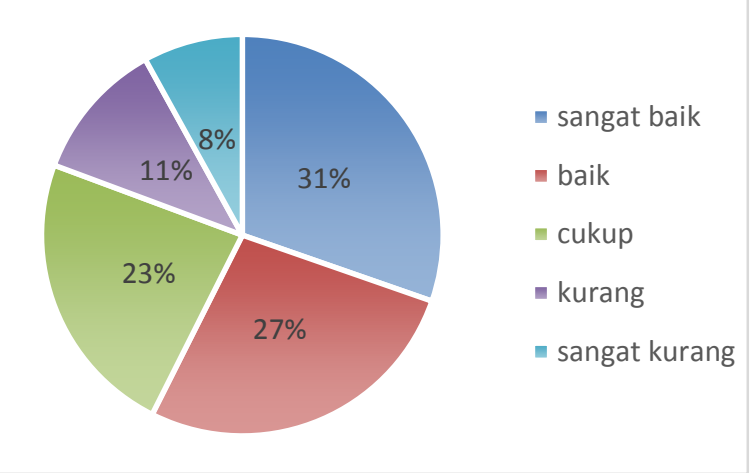

Gambar 3. Kepatuhan Masyarakat Terkait Protokol Kesehatan

Berdasarkan Gambar 3, diperoleh data bahwa sebanyak 33 responden terkategori baik dan sangat baik, mereka memilih mematuhi protokol kesehatan yang telah dirumuskan untuk diterapkan di masjid sebagai upaya pencegahan penyebaran Covid-19. Mereka setuju untuk memenuhi protokol kesehatan seperti menggunakan masker, menerapkan social distancing dengan memberikan jarak pada saf salat, tidak melakukan interaksi langsung seperti bersalaman dsb., serta protokol kesehatan lainnya. Sebagian memilih opsi tersebut dengan alasan bahwa ibadah kepada Allah wajib dilakukan sehingga aktivitas berjamaah semestinya tetap berlangsung, akan tetapi juga harus melakukan usaha untuk melakukan pencegahan, pencegahan tersebut diwujudkan salah satunya dengan menerapkan protokol kesehatan pada aktivitas berjamaah di masjid.

Sedangkan 11 responden lainnya terkategori cukup dikarenakan mereka memilih opsi netral pada pertanyaan-pertanyaan yang telah diajukan. 10 responden 
lainnya terkategori kurang dan sangat kurang, mereka memilih opsi tidak setuju pada pertanyaan terkait penerapan protokol kesehatan pada aktivitas berjamaah di masjid. Sebagian mereka beralasan bahwa di daerah mereka berada di zona hijau sehingga tidak diperlukan untuk menerapkan protokol kesehatan, sebagian lainnya beranggapan bahwa cukup berdoa dan berdzkir kepada Allah sudah cukup dilakukan agar terhindar dari wabah Covid-19. Hal lain yang membuat seseorang tidak menerapkan protokol kesehatan di masjid adalah karena masjidnya tersebut belum menerapkan protokol kesehatan. Skor rata-rata terkait kepatuhan terhadap protokol kesehatan di masjid pada masa wabah Covid-19 adalah 3,55 yang terkategori baik.

\section{Diskusi dan Analisis}

Mengulik data pada Gambar 1, persentase sikap masyarakat mengindikasikan pilihan dengan skala sikap yang semuanya hampir terpenuhi dengan variabelitas yang kecil. Data ini mengisyaratkan adanya kehati-hatian para jamaah masjid dalam memandang isu Covid-19. Sebab, secara teologis hal tersebut menyangkut kuasa Tuhan yang sangat abstrak, namun wajib diyakini. Sementara epidemilogis, isu tersebut menjadi realitas bencana non-alam sesuai Keputusan Presiden No.12 Tahun 2020, sebuah keputusan yang dianggap banyak pihak sebagai force majeure atau keadaan memaksa di luar kemampuan. Kendati demikian, para jamaah itu mempunyai kecenderungan yang baik dalam menyikapi diri terhadap bencana nasional tersebut sebagai sebuah prinsip teologis ataupun realitas epidemiologis.

Secara prinsip teologis, takdir merupakan salah satu dari enam hal yang wajib diimani oleh setiap muslim. Takdir adalah salah satu hal yang sentral, bagaimana menyikapi takdir akan sangat berpengaruh pada perilaku setiap individu dalam menjalankan kehidupan keseharian. Perbedaan prinsip dalam menyikapi takdir sejatinya telah ada sejak periode awal Islam. Hingga kini, setidaknya umat Islam dalam menyikapi takdir dalam tiga kelompok besar yakni Jabariyah, Qadariyah, dan penengah di antara keduanya.

Bagi mereka dari kelompok Jabariyah, akal dipandang berada pada posisi yang rendah, karena semua tindakan berada di luar kuasa manusia atau di bawah kuasa Tuhan. ${ }^{25}$ Manusia hanya merupakan individu-individu yag terpaksa. Ideologi yang sering disebut dengan fatalisme atau predestination ${ }^{26}$ ini menganggap apa yang diperbuat manusia adalah perbuatan Tuhan, sesuai dengan firman Allah, "Padahal Allah-lah yang menciptakan kamu dan apa yang kamu perbuat itu” dalam QS. AlSaffat ayat 96. Oleh karenanya, masyarakat dengan paham ini lebih banyak memilih untuk bersikap pasrah kepada takdir dengan tidak melakukan upaya pencegahan yang berarti. Bagi mereka, yang penting tetap beraktifitas di masjid, beribadah, dan berdoa.

${ }^{25}$ M Yunus Samad, "Pendidikan Islam Perspektif Aliran Kalam: Qadariyah, Jabariyah, Dan Asy'ariyah,” Lentera Pendidikan 16, no. 1 (2013): 77.

${ }^{26} \mathrm{Ahmad}$ Ismakun Ilyas, "Sejarah Perdebatan Hakikat Perbuatan Manusia Sebuah Telaah Deskriptif Analitik," Al-Turas 10, no. 1 (2004), 55. 
Muhammad Thohir; Nalindra Isnan Pangestu; Fiha Ainun Jariyah; Puga Sakti Wibowo

Berbeda dengan Jabariyah, Qadariyah berprinsip bahwa manusia hakikatnya telah diberikan kebebasan kehendak oleh Tuhan. Kelompok yang banyak merujuk pada Q.S. Al-Ra'd: 11 dan QS. Fussilat: 40 ini percaya bahwa segala tindakan manusia terlepas dari intervensi Allah, ${ }^{27}$ kendati Dia senantiasa mengawasi. ${ }^{28}$ Para jamaah masjid yang cenderung menyikapi wabah Covid-19 dengan usaha semaksimal mungkin agar dapat terhindar dari wabah adalah bagian dari kelompok paham ini. Namun dalam pengamatan, ada kalanya mereka agak paranoid, yakni bersikap berlebihan dengan memborong berbagai bahan makanan, masker, hand sanitizer, dan sebagainya. Setelah itu, mereka cenderung menutup diri dan enggan ikut berjamaah di masjid, sebab mereka meyakini bahwa keselamatan mereka dari wabah murni bergantung pada usaha mereka sendiri. Ikhtiar fisik menjadi lebih dominan, dari pada ikhiar batin melalui doa dan dzikir.

Berbeda dengan dua pemahaman sebelumnya, para jamaah masjid ada yang lebih memilih jalan tengah, yakni dengan menyeimbangkan diri baik dalam ikhtiar lahir maupun batin. Secara teologis, mereka memposisikan diri di antara Jabariyah dan Qadariyah. ${ }^{29}$ Paham yang disebut Abl al-Sunnah wa al-Jamaah (selanjutnya ASJ) ini mengatakan manusia mempunyai pilihan dan kehendak, ia bergerak sesuai dengan pilihannya, akan tetapi pilihan yang diambil oleh manusia tetap sesuai dengan apa yang telah ditetapkan oleh Allah Swt., sehingga dianggap lebih konsisten berada di atas manhaj Nabi Muhammad saw. dan para sahabatnya. ${ }^{30}$ Dengan teologi yang menyeimbangkan makna antara Q.S. al-Baqarah: 286 dan Q.S. al-Saffat: 96 itu, para jamaah tetap berusaha semaksimal mungkin, secara lahir ataupun batin, melakukan usaha pencegahan diri dengan beraktivitas berjamaah sesuai prosedur kesehatan. Jika mereka gagal, tetap terserang Covid-19, maka mereka meyakini usaha mereka kurang sempurna dan menganggap ada hikmah besar dibalik kegagalan yang mereka alami.

Kajian teologis yang mengupas sisi takdir bagi para jamaah ini semakin relevan jika dikaitkan dengan Covid-19 secara epidemiologis. Melalui perspektif ini, penyebutan wabah lebih merujuk pada penyebaran penyakit menular dalam jumlah lebih banyak dari biasanya dan berlangsung lama. Jika berlangsung di daerah tertenu saja disebut endemi. Sedangkan untuk daerah yang lebih luas disebut epidemi. Kendati demikian, UU No. 4 Tahun 1984 tentang wabah penyakit menular, terlihat menyepadankan antara wabah sebagai epidemi, yakni terjadinya penyebaran penderita dalam suatu masyarakat yang secara kuantitas melebihi kelazimannya. Adapun jika penyakit sudah menulari seluruh negara di dunia, maka ia disebut dengan pandemi.

\footnotetext{
${ }^{27}$ Edi Sumanto, "Akal, Wahyu, dan Kasb Manusia Menurut Jabariyah Dan Qadariyah," Manthiq 1, no. 1 (2016), 82.

${ }^{28}$ Ahmad Abdurrahim As-Sayis, “ al-Qadariyah” dalam Tim Riset Majelis Tinggi Urusan Islam Mesir, Ensiklopedi Aliran Dan Maḑ̌bab Di Dunia Islam, Pustaka Al-Kautsar (Jakarta: Pustaka Al-Kautsar, 2015), 700.

${ }^{29}$ Mahmuddin, "Qadariyah, Jabariyah dan Ahlussunnah (Studi Komparatif Merespon Kebijakan Pemerintah Dan Fatwa MUI Dalam Mencegah Penularan Covid-19).”..., 217.

${ }^{30}$ Ronny Mahmuddin, "Qadariyah, Jabariyah Dan Ahlussunnah (Studi Komparatif Merespon Kebijakan Pemerintah Dan Fatwa MUI Dalam Mencegah Penularan Covid-19)," Bustanul Fuqaha: Jurnal Bidang Hukum Islam 1, no. 2 (2020), 215.
} 
Oleh karena itu, istilah terakhir yang dipilih dan digunakan dalam artikel ini, yakni sebagai Pandemi Covid-19.

Atas dasar ini pula, maka penyebutan Pandemi Covid-19 sebagai "tentara Allah" (junûd Allah) dapat dipandang kurang relevan secara kontekstual. Sebab, frasa alegorik dalam doa wabah tersebut secara geneologis lebih banyak dikaitkan dengan azab atas umat pendurhaka. Beberapa peritiwa terkait dengan ini, di antaranya seperti wabah Virus Sampar (pestis haemorrbagica) yang menimpa Kaum Tsamud sebagai tafsir atas QS. Hûd11: 61-68, Lintah Air (limnatis nilotica) yang menimpa pasukan Thalut yang tidak taat kepada pimpinan sebagai tafsir QS. al-Baqarah: 249, dan virus cacar api (varicella-zoster) yang menimpa pasukan Raja Abrahah al-Asyram sebagai tafsir atas QS. al-Fil: 3-5. ${ }^{31}$ Sedangkan sebagai sebuah pandemi, peta epidemiologis penyebaran virus Covid-19 tidak hanya menyerang para pendurhaka, tetapi juga kepada semua orang dan negara di dunia dalam lintas etnis, agama, dan level sosial. Bahkan, dalam catatan kaleidoskop 2020 oleh Rabithah Ma'abid Islamiyah (RMI) PBNU, dilaporkan bahwa 207 ulama dan pengurus pesantren wafat di masa pandemi Covid-19 (nu.or.id, 17/12/2020). ${ }^{32}$ Oleh karena itu, realitas ini lebih membawa pemaknaan Covid-19 sebagai tentara setan daripada tentara Allah. Virus sebagai bagian dari tentara setan ini dapat dijumpai dalam tafsir atas penyakit menahun yang diderita oleh Nabi Ayyub dalam QS. Shâd: 44.

Secara epidemiologis, serangan pandemi biasanya akan diukur berdasarkan indikator-indikator terkait, (1) attack rate (AR), yakni jumlah kasus terkonfirmasi dibandingkan dengan jumlah populasi, (2) case fatality rate (CFR), yakni jumlah kasus kematian dibandingkan dengan jumlah kasus konfirmasi, (3) case recovery rate (CRR), yaitu jumlah pasien yang mengalami kesembuhan, dan (4) positive rate yaitu jumlah kasus terkonfirmasi dibandingkan dengan jumlah yang diperiksa. Dari indikatorindikator tersebut, peta epidemiologis Covid-19 di Kota Surabaya tahun 2020 sempat menjadi zona merah tua (kompas.com, 04/06/2020). Windu Puromo, ahli epidemiologi dari Universitas Airlangga menyebutkan bahwa itu artinya Surabaya belum aman, akibat kebijakan Pembatasan Sosial Berskala Besar (PSBB) tidak berjalan sesuai dengan harapan (bbc.com, 04/06/2020).

Relasi diskusional konsep takdir dengan pandemi juga telah tercermin dalam respon para jamaah masjid terhadap pandemi Covid-19. Gambar 2 sangat menarik, di mana responden yang sangat setuju dan sangat tidak setuju hanya selisih 1 persen. Persentase jumlah mereka yang bersikap mendukung penutupan masjid sebagai pertimbangan pencegahan wabah Covid-19 atau mendukung pembukaan masjid selama wabah Covid-19 dengan mempertimbangkan kondisi serta menerapkan protokol kesehatan hampir berimbang. Bagi yang setuju, maka mereka mengikuti

${ }^{31}$ Husnul Hakim, "Epidemi dalam Alquran: Suatu Kajian Tafsir Maudhu'I dengan Corak Ilmi,” Kordinat, Vol. 17, No.1, (April 2018), 113-128.

${ }^{32}$ Sumber: https://www.nu.or.id/post/read/125349/kaleidoskop-2020--ratusan-ulamawafat-di-masa-pandemi-covid-19. 
Muhammad Thohir; Nalindra Isnan Pangestu; Fiha Ainun Jariyah;

Puga Sakti Wibowo

aktivitas berjamaah di masjid dengan selalu memperhatikan kondisi dan menerapkan protokol kesehatan yang sudah ditetapkan oleh pemerintah dan takmir.

Mereka tidak hanya melakukan usaha dengan memperhatikan protokol kesehatan serta menjaga kesehatan agar tetap prima, tetapi juga melakukan usaha yang bersifat batin seperti berdoa dan berzikir agar dihindarkan oleh Allah dari wabah Covid-19. Setelah berusaha semaksimal mungkin sesuai dengan kondisi mereka, mereka akan memasrahkan usaha mereka kepada Allah. Mereka meyakini bahwa apabila mereka sudah melakukan upaya pencegahan akan tetapi masih tertular virus dan meninggal karenanya akan termasuk mati syahid sebagaimana disabdakan oleh Rasulullah saw. Responden yang bersikap demikian dapat digolongkan dalam kelompok yang cenderung bersikap berdasarkan teologi ASJ.

Dari ketiga analisis tipologi respons masyarakat terkait kegiatan berjamaah di masjid pada masa pandemi dapat diketahui bahwa respon yang mendukung upaya penanggulangan Covid-19 dengan baik adalah masyarakat yang menyikapinya cenderung pada prinsip ASJ. Selain melakukan upaya pencegahan dan penanggulangan, kelompok ASJ juga memiliki konsep tawakal dengan memasrahkan kepada Tuhan atas usaha-usaha yang telah mereka lakukan. Jumlah penganut teologi ASJ sangat besar dan menjadi mayoritas teologi yang diikuti oleh umat Islam. Akan tetapi berdasarkan sajian data yang telah dipaparkan sebelumnya diketahui bahwa walaupun mayoritas masyarakat mengaku mengikuti teologi ASJ tetapi tidak semua masyarakat menyikapi Pandemi Covid-19 ini sesuai dengan prinsip dalam teologi ASJ.

Mayoritas umat Islam menyebut diri mereka menganut teologi ASJ atau biasa juga disebut Sunni. Dalam riset yang dilakukan oleh The Pew Forum on Religion \& Public Life pada tahun 2009 ditemukan bahwa 87-90\% umat Islam di Dunia adalah Islam Sunni. ${ }^{33}$ Di Indonesia sendiri umat Islam didominasi oleh dua ormas besar, yakni Muhammadiyah dan NU. Muhammadiyah sebagaimana disampaikan oleh Yunahar Ilyas berafiliasi pada manhaj salaf, yakni berpegang teguh dengan al-Quran dan Al-Sunnah, tidak terikat dengan aliran teologis, madzhab fiqh dan tariqah shufiyah mana pun. Manbaj Salaf adalah bagian dari ASJ. ${ }^{34}$ Sedangkan NU tertulis jelas dalam AD/ARTnya bahwa NU berakidah Islam menurut paham ASJ dalam bidang akidah mengikuti mazhab Imam Abu Hasan al-Asy'ari dan Imam Abu Mansur al-Maturidi. ${ }^{35}$

ASJ sebagaimana telah penulis paparkan sebelumnya, mereka memiliki prinsip bahwa manusia memiliki kehendak dan bergerak sesuai dengan keinginannya, akan tetapi setiap pilihan yang diambil oleh manusia akan tetap berada pada takdir yang telah ditetapkan oleh Allah. Sehingga dalam teologi ASJ, seseorang tetap untuk

${ }^{33}$ Luis Lugo, Mapping The Global Muslim Population: A Report on the Size and Distribution of the World's Muslim Population, 2009, 1.

${ }^{34}$ Yunahar Ilyas, "Paham Agama Islam Dalam Muhammadiyah: Salaf Dan Tajdid," in Pengajian Ramadhan 1438 H (Yogyakarta, 2017).

35Pengurus Besar Nahdlatul Ulama, Anggaran Dasar Dan Rumah Tangga Nabdlatul Ulama, II. (Jakarta: Lembaga Ta'lif wan Nasyr PBNU, 2015), 38. 
berusaha semaksimal mungkin sesuai dengan keadaannya serta diiringi dengan doa dalam setiap usahanya. Setelah melakukan usaha serta doa yang telah dipanjatkan, seseorang akan memasrahkan semua usaha yang telah dilakukannya kepada Allah dan terus diiringi dengan doa.

Tidak baru-baru ini saja umat Islam merasakan wabah. Hal ini bisa ditemukan dalam hadis-hadis Nabi saw., para sahabat dan generasi-generasi setelahnya yang membahas terkait wabah. Di antaranya, pelajaran bagaimana umat Islam terdahulu dalam menyikapi wabah. Pelajaran tersebut cukup penting untuk dipahami kembali sebagai bahan pertimbangan dalam menyikapi wabah di era sekarang.

Dalam sebuah hadis yang diriwayatkan oleh Imam Bukhari dan Muslim sebagaimana dikutip oleh Mukharom dan Havis Aravik, Rasulullah saw. mengatakan apabila mendengar terjadi wabah yang melanda suatu negeri, maka jangan memasukinya. Tetapi jika terjadi wabah di negeri sendiri, maka janganlah keluar darinya. Instruksi Rasulullah tersebut bertujuan agar wabah tidak menjalar di negerinegeri sekitarnya, dan Rasulullah menjanjikan kepada orang-orang yang negerinya dilanda wabah dan bersabar untuk tinggal akan mendapatkan pahala sebagai mujahid dan mengancam orang yang keluar dari negeri yang terkena wabah dengan kebinasaan. Dalam hadis lain juga ditemukan instruksi Rasulullah yang diriwayatkan oleh Imam Muslim bahwa Rasulullah menginstruksikan agar kita menjauhi orang yang terkena lepra sebagaimana kita menjauhi singa. ${ }^{36}$

Syukri Al Fauzi Harlis Yurnalis mengutip sebuah kisah yang terjadi pada masa Khalifah Umar bin Khattab, beliau dan para rombongan hendak memasuki negeri Syam. Pada saat itu beliau mendapatkan kabar bahwa di negeri Syam sedang terjadi wabah, kemudian beliau berunding dengan para rombongan yang bersamanya. Keputusan yang diambil beliau adalah tidak jadi memasuki kota Syam dan kembali lagi ke Madinah. Abu Ubaidah bin Al-Jarrah tidak setuju dengan keputusan Khalifah Umar dengan mengatakan "apakah engkau lari dari takdir Allah?", perkataan tersebut dijawab denga arif oleh Khalifah Umar "aku lari dari takdir Allah dan menuju takdir Allab lainnya" ${ }^{37}$

Selanjutnya Abdurrahman bin Auf mengingatkan, bahwa Nabi pernah menasehati sahabat untuk tidak memasuki daerah yang terkena wabah dan warga di dalamnya tidak keluar dari daerah yang terjangkiti wabah. Dari hadis tersebut dapat diambil pelajaran bahwa umat muslim terdahulu tidak hanya sekedar pasrah terhadap takdir, tetapi juga melakukan sebuah upaya pencegahan serta penanggulangan, salah satu dengan kebijakan pembatasan sosial. Adapun realitas yang mengemukakan kebijakan pembatasan tidak berjalan sesuai dengan harapan, itu terjadi karena respon masyarakat yang tidak seragam.

${ }^{36}$ Mukharom and Havis Aaravik, "Kebijakan Nabi Muhammad Saw Menangani Wabah Penyakit Menular Dan Implementasinya Dalam Konteks Menanggulangi Coronavirus Covid-19," SALAM: Jurnal Sosial \& Budaya Syar-i 7, no. 3 (2020), 242.

${ }^{37}$ Syukri Al Fauzi Harlis Yurnalis, "Covid-19: Perspektif Kalam Dalam Takdir Antara Qadariyah Jabariyah Dan Tawakal,” Jurnal Al-Aqidab: Jurnal Ilmu Akidah Filsafat 12, no. 1 (2020), 84. 
Muhammad Thohir; Nalindra Isnan Pangestu; Fiha Ainun Jariyah; Puga Sakti Wibowo

Dalam menyikapi kegiatan berjamaah di masjid pada masa wabah Covid-19 berdasarkan teologi ASJ, seharusnya tidak hanya sekedar pasrah dengan membuka masjid dan beraktivitas di sana seperti biasanya dan memasrahkan takdirnya kepada Allah saja. Hal ini tentu bertentangan dengan prinsip teologi ASJ. Tidak seharusnya juga masyarakat menjadi terlalu paranoid terhadap wabah Covid-19 dan melakukan upaya yang berlebihan dalam menyikapinya sehingga seolah-olah mereka tidak memiliki penolong, padahal Allah adalah sebaik-baik penolong.

Sukri Al-Fauzi mengutip sebuah riwayat yang mengisahkan pernah ada seseorang yang tidak mengikat kudanya dengan benar, melihat hal itu Nabi saw. bertanya, "kenapa tidak engkau ikat untamu?", sahabat tersebut menjawab bahwa ia bertawakal kepada Allah, mendengar hal itu Rasulullah saw. menyampaikan agar ia mengikat untanya kemudian bertawakal kepada Allah. ${ }^{38}$ Hadis tersebut mengindikasikan agar seseorang tidak hanya sekedar tawakal tanpa melakukan apa pun, akan tetapi seharusnya melakukan usaha terlebih dahulu kemudian bertawakal. Begitu juga dengan konteks Covid-19 ini, tidak hanya sekedar pasrah dengan takdir, akan tetapi juga turut melakukan ikhtiar dalam mencegahnya.

Sikap yang baik berdasarkan ASJ adalah seyogyanya masyarakat tetap tenang dalam menyikapi wabah ini akan tetapi tidak sampai bersikap sembrono. Tetap tenang dengan mengikuti arahan dari pihak yang berwenang, berdoa kepada Allah dan pasrah terhadap takdir setelah melakukan usaha dan doa yang dipanjatkan. Sikap seperti inilah yang semestinya diterapkan oleh segenap masyarakat sehingga wabah bisa dikendalikan dan dihentikan penyebarannya.

Terdapat sebuah peristiwa pada masa Ibnu Hajar al-Asqalani ketika terjadi wabah di wilayahnya. Pada masa itu terjadi wabah, kemudian orang-orang berkumpul di padang pasir untuk melakukan berdoa bersama, men-qiyas-kan shalat tolak bala' dengan salat istisqa'. Yang terjadi adalah wabah semakin besar dan semakin banyak orang yang menjadi korban. Oleh karena itu Ibnu Hajar selalu menolak untuk hadir di acara tolak pandemi yang diselenggarakan oleh pihak kerajaan. Ibnu Hajar berpendapat bahwa men-qiyas-kan istisqa' dengan tolak bala' adalah perbuatan bid'ah. ${ }^{39}$ jika dikorelasikan dengan konteks dalam menanggulangi Covid-19, tidak dianjurkan untuk mengumpulkan banyak masa dalam satu tempat dengan tujuan melakukan doa bersama dan sejenisnya, karena adanya kerumunan masa adalah salah satu faktor yang menyebabkan semakin banyak orang yang tertular wabah.

Majelis Ulama Indonesia (MUI) mengeluarkan fatwa bahwa yang mengatakan jika berada di wilayah dengan potensi penularan Covid-19 yang tinggi, maka diperbolehkan untuk meninggalkan salat Jumat dan menggantinya dengan salat zuhur di kediaman masing-masing, serta meninggalkan jamaah salat lima waktu, tarawih dan Id di masjid atau tempat-tempat umum lainnya. Pada poin berikutnya disebutkan jika Tawakal, 86."

${ }^{38}$ Yurnalis, "Covid-19: Perspektif Kalam Dalam Takdir Antara Qadariyah Jabariyah Dan

${ }^{39}$ Saifuddin Zuhri Qudsy and Ahmad Sholahuddin, "Kredibilitas Hadis Dalam Covid-19: Studi Atas Bazl Al-Maun fi Fadhli Al-Thaun Karya Ibnu Hajar Al-Asqalany," Al-Quds: Jurnal Studi Alquran dan Hadis 4, no. 1 (2020). 
berada di wilayah dengan potensi penularan yang rendah maka hukumnya wajib untuk salat berjamaah di masjid dengan mengikuti protokol kesehatan seperti selalu menggunakan masker, mencuci tangan, tidak melakukan kontak fisik antar jamaah dan lain sebagainya.

Selain itu pemerintah melalui Menteri Agama juga menghimbau kepada pengurus masjid untuk melakukan upaya pencegahan seperti menggulung karpet, menyemprotkan desinfektan dan lainnya. ${ }^{40}$ Di sisi lain Presiden RI, Joko Widodo sebagaimana dikutip dalam detiknews mengatakan bahwa Pemerintah melalui Kemenag RI menghimbau agar setiap umat beragama meningkatkan kualitas dan kuantitas ibadahnya masing-masing. Dan setiap aktivitas peribadatan dilakukan sesuai dengan protokol kesehatan. ${ }^{41}$ Sikap Pemerintah dan MUI sejatinya telah menggunakan prinsip teologi Abl al-Sunnah wa al-Jamaah dengan mengeluarkan himbauan pencegahan akan tetapi juga menghimbau agar meningkatkan ibadah.

Syariat bertujuan untuk menjaga kemaslahatan, dan semestinya syariat juga bertujuan untuk mencegah dan menghilangkan kerusakan-kerusakan. Apabila terjadi pertentangan antara dua kemaslahatan, maka yang harus direalisasikan adalah memilih yang paling utama dengan mengabaikan yang tidak terlalu penting. Sebaliknya, apabila ada dua kerusakan (mafsadat) saling bertentangan, yang diambil pijakan adalah yang paling kecil risikonya. ${ }^{42}$ Hudzaifah Achmad Qotadah mengatakan bahwa penangguhan salat berjamaah di tempat ibadah tidak berarti bermaksud menomor dua kan bifdz, al-din. Penangguhan sementara pelaksanaan salat berjamaah di masjid selama masa wabah Covid-19 bermaksud sebagai usaha untuk mencegah kemudharatan. Walaupun masjid ditutup, akan tetapi pelaksanaan shalat yang merupakan aspek dharury tetap dilaksanakan sehingga tidak bertentangan dengan hifdr. al-din. ${ }^{43}$ Sudah semestinya dengan ini masyarakat tidak lagi menolak mentah-mentah penutupan masjid pada masa wabah Covid-19, karena hal itu adalah bagian dari usaha untuk mencegah dan menghentikan penyebarannya dan juga tidak bertentangan dengan prinsip teologi Abl al-Sunnah wa al-Jamaah.

Sementara dari segi kepatuhan, Gambar 3 mengungkapkan bahwa sikap kepatuhan masyarakat terkait protokol kesehatan terlihat dalam persentase tinggi. Disinyalir, masyarakat telah mengikuti instruksi yang telah dikeluarkan oleh pemerintah, MUI, ormas-ormas Islam, terkait pelaksanaan kegiatan berjamaah di

${ }^{40}$ Callistasia Wijaya, "Virus Corona: MUI Keluarkan Fatwa Penyelenggaraan Ibadah Di Tengah Wabah Covid-19," BBC News, last modifId March 13, 2020, accessed July 25, 2020, www.bbc.com/indonesia/indonesia-51867023.

${ }^{41}$ Tim Detikcom, "Jokowi: Pemerintah Tidak Larang Ibadah Tapi Atur Peribadatan," DetikeNews, last modifId May 19, 2020, accessed July 25, 2020, www.detik.com/news/berita/d5020480/jokowi-pemerintah-tidak-larang-ibadah-tapi-atur-peribadatan.

${ }^{42}$ Yusuf Qardhawi, Membumikan Islam: Keluasan Dan Keluwesan Syariat Islam Untuk. Manusia, terj. Ade Nurdin Dan Riswan, ed. Tiar Anwar Bachtiar and Toto Edidarmo (Bandung: PT Mizan Pustaka, 2018), 63-68.

${ }^{43}$ Hudzaifah Achmad Qotadah, "Covid-19: Tinjauan Maqasid Al-Shariah Terhadap Penangguhan Pelaksanaan Ibadah Salat Di Tempat Ibadah (Hifdz Al-Nafs Lebih Utama Dari Hifdz Al-Din?)," SALAM: Jurnal Sosial \& Budaya Syar-i 7, no. 7 (2020), 667. 
Muhammad Thohir; Nalindra Isnan Pangestu; Fiha Ainun Jariyah;

Puga Sakti Wibowo

masjid. Instruksi tersebut sejatinya menjadi salah satu upaya untuk memutus mata rantai penularan sehingga wabah bisa segera dikendalikan dan dihilangkan. Walaupun kegiatan berjamaah di masjid dibatasi dengan ditutupnya masjid ataupun diwajibkan untuk selalu menaati protokol kesehatan di masjid, masyarakat diharapkan terus meningkatkan kuantitas dan kualitas ibadahnya serta berdoa kepada Allah agar wabah ini segera diangkat sehingga segala aktivitas bisa berjalan dengan normal. Masyarakat seyogyanya juga tetap tenang dengan tetap memperhatikan protokol kesehatan, berikhtiar kemudian tawakal. Jika terkena wabah walaupun telah berusaha, maka yang terbaik adalah tetap tenang dan bersabar serta tetap melakukan usaha untuk mengobatinya. Jika seseorang meninggal karena wabah walaupun sudah melakukan berbagai usaha, maka selama dia masih bertauhid kepada Allah, dan dia termasuk meninggal dalam keadaan syahid.

Status kematian semacam inilah yang oleh Suryadilaga ${ }^{44}$ dianggap lebih mengedepankan kemanusiaan, sebuah intepretasi berbasis integrasi-interkoneksi atas hadis tentang syahid karena pandemi. Kematian yang bukan asal berani menghadapi pandemi itu sendiri, akan tetapi keberanian untuk berusaha menjalani kegiatan primer kehidupan, sekaligus mengikuti prosedur kesehatan yang ketat. Bahkan, pemenuhan prosedur kesehatan sambil menjalani shalat berjamaah dapat penulis kategorikan, dalam istilah Souza (2020), sebagai sebuah religious material. ${ }^{45}$ Souza mengungkapkan bahwa perubahan perilaku keagamaan yang dipicu akibat tekanan kondisi pandemi covid-19 bukan semata-mata karena ide-ide, melainkan justru karena perubahan material sebagai instrumen keagamaan yang muncul. Premis Souza ini memperkuat simpulan penelitian Meza (2020) yang menyebutkan bahwa dalam menghadapi pandemi diperlukan peningkatan religiusitas masyarakat. ${ }^{46}$

Sikap yang menjelaskan tentang ikhtiar berbasis keyakinan dan keimanan (i'tiqadiyyah) kepada qada' dan qadar Allah swt dalam pandemi juga ditunjukkan oleh para ulama terdahulu. Di antaranya, tercatat dari tulisan Sidy Ahmad bin 'Ajibah (w. 1224 H/1808 M) dalam kitabnya, "Silk ad-Durar fi Dzikr al-Qadhi' wa alQadar." Kitab ini lebih berperan sebagai panduan fatwa dalam perspektif teologis di tengah terjadinya wabah Tha'un tahun 1214 H/1799 M. Fatwa di dalamnya diikuti dengan berbagai rujukan Alquran dan Hadis menjadi argumentasi yang mempertajam analisisnya, di samping mengutip berbagai pendapat salafus salih dan ulama ASJ yang beraqidah 'asy'ariyyah. Beragam sikap ulama terdahulu saat menghadapi wabah telah dikategorikan oleh Khoirun Niam dalam beberapa perspektif, yaitu intelektual/aqly,

\footnotetext{
${ }^{44}$ Muhammad Alfatih Suryadilaga, "Pemahaman Hadis Tentang Covid-19 Dalam Perspektif Integrasi-Interkoneksi Amin Abdullah,” Khazanah: Jurnal Studi Islam dan Humaniora, Vol. 18 (2), 2020, pp. 173-196. DOI: http://dx.doi.org/10.18592/khazanah.v18i2.3795

${ }^{45}$ Souza, P.R.D. "Protection masks with religious motifs: COVID-19 produces new religious materiality". International Journal of Latin American Religions, 4, (18 September2020): 402-416 https://doi.org/10.1007/s41603-020-00117-z

${ }^{46}$ Meza, Diego.” In a Pandemic Are We More Religious? Traditional Practices of Catholics and the COVID-19 in Southwestern Colombia". International Journal of Latin American Religions, 4, (31 August 2020). pp. 218-234.https://doi.org/10.1007/s41603-020-00108-0
} 
teologis/i'tiqady, hukum/syar'y, ritual/ubudiyah, mistik/ghaiby, astronomik, psikologis/nafsy, dan social/ijtima'iy. ${ }^{47}$ Dengan demikian, sikap masyarakat secara teologis/itiqady yang tetap memilih shalat berjamah dengan mengkondisikan masjid yang bersih dan kondisi personal sesuai jamaah sesuai prosedur kesehatan yang ketat mendapatkan justifikasi secara normatif historis dari sikap para ulama terdahulu.

\section{Simpulan}

Masyarakat dalam menyikapi aktivitas berjamaah di masjid pada masa wabah Covid-19 ini terbagi dalam tiga kelompok. Pertama, masyarakat yang cenderung pada prinsip akidah Jabariyah. Yakni mereka yang cenderung pasrah dalam menyikapi wabah ini, tetap melakukan aktivitas di masjid seperti biasa tanpa mengikuti protokol kesehatan. Mereka meyakini bahwa manusia tidak memiliki kuasa atas perilaku mereka. Kedua, mereka yang cenderung pada prinsip akidah Qadariyah. Yakni mereka yang cenderung paranoid atau melakukan usaha yang berlebihan, takut untuk melakukan aktivitas berjamaah di masjid serta mendukung sepenuhnya masjid ditutup selama wabah Covid-19. Mereka meyakini bahwa mereka selamat dari wabah hanya atas usaha mereka sendiri. Ketiga, mereka yang bersikap pertengahan, cenderung pada prinsip teologi Asy'ariyah Maturidiyyah yang menjadi akidah ASJ.

Kelompok dengan teologi ASJ lebih bersikap tenang dalam menyikapi wabah Covid-19. Mereka melakukan usaha agar terhindar dari wabah, mendukung penutupan masjid dengan kondisi tertentu, dan juga mendukung agar kegiatan berjamaah di masjid dilaksanakan dengan mengikuti protokol kesehatan. Respons masyarakat terkait kegiatan berjamaah di masjid pada masa pandemi yang sesuai serta mendukung upaya pencegahan dan penanggulangan wabah Covid-19 adalah respons masyarakat yang cenderung pada prinsip teologi ASJ, yakni mengambil jalan tengah. Tidak hanya sekedar melakukan usaha secara zabir seperti mengikuti disiplin prosedur kesehatan yang ditetapkan oleh Tim Gugus Covid-19, akan tetapi para jamaah juga melakukan usaha batiniyah dengan berzikir dan berdoa. Setelah berusaha semaksimal mungkin baik seacara labiriyah dan batiniyah, mereka memasrahkan segala usaha mereka kepada Allah, sehingga mereka lebih mampu bersikap tenang dalam menyikapi pandemi ini. Pilihan ini secara teologis ternyata mendapatkan penguatan justifikasi secara normatif historis.

\section{Daftar Pustaka}

Abolfotouh, M.A., Almutairi, A.F., BaniMustafa, A.A. et al. "Perception and Attitude of Healthcare Workers in Saudi Arabia With Regard to Covid-19 Pandemic

\footnotetext{
${ }^{47}$ Khorun Niam, "Belajar Dari Cara Penyikapan Ulama Terdahulu Dalam Menghadapi Pandemi,' Arrabim.id: Menyuarakan Islam Damai, (17 Mei 2020), https://arrahim.id/kn/belajar-daricara-penyikapan-ulama-terdahulu-dalam-menghadapi-pandemi-bag-1/. Artikel kedua/lanjutannya dapat diakses di: https://arrahim.id/kn/belajar-dari-cara-penyikapan-ulama-terdahulu-dalammenghadapi-pandemi-bag-2-habis/
} 
Muhammad Thohir; Nalindra Isnan Pangestu; Fiha Ainun Jariyah;

Puga Sakti Wibowo

and Potential Associated Predictors”. BMC Infect Dis 20, 719, (2020).

Alwi, M.M., "Pemberdayaan Ekonomi Masyarakat Berbasis Masjid di Tengah Pandemi Covid-19," Jurnal Al-Hikmah: Ilmu Dakwah dan Perkembangan Masyarakat, Vol. 18, No. 1, (2020).

Buana, Dana Riksa. "Analisis Perilaku Masyarakat Indoensia Dalam Menghadapi Pandemi Virus Corono (Covid-19) Dan Kiat Menjaga Kesejahteraan Jiwa." SALAM: Jurnal Sosial \& Budaya Syar-i 7, no. 3 (2020).

Di Gennaro, Francesco, Damiano Pizzol, Claudia Marotta, Mario Antunes, Vincenzo Racalbuto, Nicola Veronese, and Lee Smith. "Coronavirus Diseases (COVID-19) Current Status and Future Perspectives: A Narrative Review." International Journal of Environmental Research and Public Health 17, no. 8 (2020).

Hakim, H. "Epidemi dalam Alquran: Suatu Kajian Tafsir Maudhu'i dengan Corak Ilmi," Kordinat, Vol. 17, No.1, (April 2018), 113-128.

Hammad, M.A.H., Eissa, M. \& Dawa, G.A. "Impact of Coronavirus Disease 2019 (COVID-19) Pandemic on Attitude, Behavior, and Mental Health of Patients with Rheumatic diseases." Egypt Rheumatol Rehabil 47, 45 (2020).

Hidayah, N. "Dari Jabariyah, ke Qadariyah, hingga islam progresif: respons muslim atas pandemi Covid-19 di Indonesia," Salam; Jurnal Sosial \& Budaya Syar-i, Vol. 7, No. 5, (2020), 423-438.

Gorbianto, Marchio Irfan. "Breaking: Jokowi Announces Indonesia's First Two Confirmed COVID-19 Cases." The Jalarta Post. Accessed June 29, (2020). https://www.thejakartapost.com/news/2020/03/02/breaking-jokowiannounces-indonesias-first-two-confirmed-Covid-19-cases.html.

Ilyas, Ahmad Ismakun. "Sejarah Perdebatan Hakikat Perbuatan Manusia Sebuah Telaah Deskriptif Analitik." Al-Turas 10, no. 1 (2004).

Ilyas, Yunahar. "Paham Agama Islam Dalam Muhammadiyah: Salaf Dan Tajdid." In Pengajian Ramadhan 1438 H. Yogyakarta, (2017).

Lestari, S., "Sikap Warga Kampung Wisata Warna-Warni (Nani) Terhadap Pandemi Covid-19.” Seminar Nasional Psikologi UM, (2020).

Lugo, Luis. Mapping The Global Muslim Population: A Report on the Size and Distribution of the World's Muslim Population. Washington, (2009).

Mahmuddin, R. \& Syandri, S. "Qadariyah, Jabariyah dan Ahlus Sunnah (Studi Komparatif Merespon Kebijakan Pemerintah dan Ulama Mencegah Merebaknya Covid-19)," Bustanul Fuqaha: Jurnal Bidang Hukum Islam, Vol.1, No.2, (2020), 209-222.

Majelis Ulama Indonesia. "Fatwa Majelis Ulama Indonesia Nomor: 14 Tahun 2020 Tentang Penyelenggaraan Ibadah Dalam Situasi Terjadi Wabah Covid-19," n.d.

Mesir, Tim Riset Majelis Tinggi Urusan Islam. Ensiklopedi Aliran Dan Madzhab Di Dunia Islam. Pustaka Al-Kautsar. Jakarta: Pustaka Al-Kautsar, 2015.

Meza, Diego." In a Pandemic Are We More Religious? Traditional Practices of Catholics and the COVID-19 in Southwestern Colombia". International Journal of Latin American Religions, 4, (31 August 2020). pp. 218- 
234.https://doi.org/10.1007/s41603-020-00108-0

Miles, M.B., Huberman, A.M., \& Saldana, J. Qualitative Data Analysis: A Methods Sourcebook, Fourth Edition, Sage Publishing, (2014).

Muhammadiyah, Pimpinan Pusat. "Edaran Pimpinan Pusat Muhammadiyah Nomor 02/EDR/1.0/E/2020 Tentang Tuntunan Ibadah Dalam Kondisi Darurat Covid-19," n.d.

Mukharom, and Havis Aaravik. "Kebijakan Nabi Muhammad Saw Menangani Wabah Penyakit Menular Dan Implementasinya Dalam Konteks Menanggulangi Coronavirus Covid-19." SALAM: Jurnal Sosial \& Budaya Syar$i 7$, no. 3 (2020).

Muri yusuf, A. Metode Penelitian: Kuantitatif, Kualitatif, Dan Penelitian Gabungan. Jakarta : Kencana. Jakarta: Kencana, (2014).

Muttaqin, H., Wahidin, K., Maulana, M.A., \& Juarsih, J. "Pemberdayaan Jamaah Masjid Dan Penanggulangan Dampak Pandemi Covid-19: Studi Lapangan Masjid Baitul Mukhlisin, Desa Pangkalan, Kecamatan Ciawigebang, Kuningan," An-Nufus: Jurnal Kajian Islam, Tasawuf, dan Piskoterapi, Vol.2, No. 1, (2020).

Niam, Khorun "Belajar Dari Cara Penyikapan Ulama Terdahulu Dalam Menghadapi Pandemi,' Arrabim.id: Menyuarakan Islam Damai, (17-18 Mei 2020), https://arrahim.id/kn/belajar-dari-cara-penyikapan-ulama-terdahulu-dalammenghadapi-pandemi-bag-1/. Ini bagian pertama. Bagian kedua di: https://arrahim.id/kn/belajar-dari-cara-penyikapan-ulama-terdahulu-dalammenghadapi-pandemi-bag-2-habis/.

Qardhawi, Yusuf. Membumikan Islam: Keluasan Dan Keluwesan Syariat Islam Untuk Manusia, Terj. Ade Nurdin Dan Riswan. Edited by Tiar Anwar Bachtiar and Toto Edidarmo. Bandung: PT Mizan Pustaka, 2018.

Qotadah, Hudzaifah Achmad. "Covid-19: Tinjauan Maqasid Al-Shariah Terhadap Penangguhan Pelaksanaan Ibadah Salat Di Tempat Ibadah (Hifdz Al-Nafs Lebih Utama Dari Hifdz Al-Din?)." S ALAM: Jurnal Sosial \& Budaya Syar-i 7, no. 7 (2020).

Qudsy, Saifuddin Zuhri, and Ahmad Sholahuddin. "Kredibilitas Hadis Dalam Covid19: Studi Atas Bazl Al-Maun Fi Fadhli Al-Thaun Karya Ibnu Hajar AlAsqalany." Al-Quds: Jurnal Studi Alquran dan Hadis 4, no. 1 (2020).

Samad, M Yunus. "Pendidikan Islam Perspektif Aliran Kalam: Qadariyah, Jabariyah, Dan Asy'ariyah." Lentera Pendidikan 16, no. 1 (2013).

Sholikhah, Amirotun. "Statistika Desktiptif Dalam Penelitian Kualitatif." Komunika 10, no. 2 (2016).

Souza, P.R.D. "Protection masks with religious motifs: COVID-19 produces new religious materiality". International Journal of Latin American Religions, 4, (18 September 2020)

Sumanto, Edi. "Akal, Wahyu, Dan Kasb Manusia Menurut Jabariyah Dan Qadariyah." Manthiq 1, no. 1 (2016).

Suryadilaga, Muhammad Alfatih, "Pemahaman Hadis Tentang Covid-19 Dalam 
Muhammad Thohir; Nalindra Isnan Pangestu; Fiha Ainun Jariyah;

Puga Sakti Wibowo

Perspektif Integrasi-Interkoneksi Amin Abdullah," Khazanah: Jurnal Studi Islam dan Humaniora, Vol. 18 (2), 2020, pp. 173-196. DOI: http://dx.doi.org/10.18592/khazanah.v18i2.3795

Tim Detikcom. "Jokowi: Pemerintah Tidak Larang Ibadah Tapi Atur Peribadatan." DetikNews. Last modifId May 19, 2020. Accessed July 25, (2020). www.detik.com/news/berita/d-5020480/jokowi-pemerintah-tidak-larangibadah-tapi-atur-peribadatan.

Ulama, Pengurus Besar Nahdlatul. Anggaran Dasar Dan Rumah Tangga Nahdlatul Ulama. II. Jakarta: Lembaga Ta’lif wan Nasyr PBNU, (2015).

Utami, R.A., Mose, R.E., \& Martini, "Pengetahuan, Sikap dan Keterampilan Masyarakat dalam Pencegahan COVID-19 di DKI Jakarta," Jurnal Kesehatan Holistic, vol. 4, no. 2, (2020).

Wijaya, Callistasia. "Virus Corona: MUI Keluarkan Fatwa Penyelenggaraan Ibadah Di Tengah Wabah Covid-19." BBC News. Last modifId March 13, 2020. Accessed July 25, 2020. www.bbc.com/indonesia/indonesia-51867023.

World Health Organization (WHO). "Novel Coronavirus." World Health Organization. Last modifId 2020. Accessed June 26, 2020. https://www.who.int/indonesia/news/novel-coronavirus/qa-for-public.

Yurnalis, Syukri Al Fauzi Harlis. "Covid-19: Perspektive Kalam Dalam Takdir Antara Qadariyah Jabariyah Dan Tawakal." Jurnal Al-Aqidab: Jurnal Ilmu Akidah Filsafat 12, no. 1 (2020).

"Risiko Penularan Corona Tinggi Alasan Tempat Ibadah Ditutup." CNN Indonesia, n.d. Accessed July 13, 2020. www.cnnindonesia.com/nasional/20200528160434-20-507677/risikopenularan-corona-tinggi-alasan-tempat-ibadah-ditutup.

"Sensus Penduduk 2010 - Penduduk Menurut Wilayah Dan Agama Yang Dianut Indonesia." Accessed June 26, 2020. https://sp2010.bps.go.id/index.php/site/tabel?tid=321\&wid=0. 